\title{
FERMENTASI SUBSTRAT PADAT DAN SUBSTRAT CAIR UNTUK PRODUKSI ASAM LAKTAT DARI KULIT PISANG DENGAN RHIZOPUS ORYZAE
}

\author{
Ery Susiany Retnoningtyas*, Aning Ayucitra, Fandy Maramis, \\ Ong Wei Yong, Frengky W. Pribadi, Nelsi K. Tanti \\ Laboratorium Teknologi Bioproses, Jurusan Teknik Kimia, Fakultas Teknik \\ Universitas Katolik Widya Mandala Surabaya \\ Jalan Kalijudan 37, Surabaya 60114 \\ Email: ery.srt@gmail.com
}

\begin{abstract}
Abstrak
Sebagai negara tropis, Indonesia merupakan salah satu negara penghasil pisang terbesar. Berbagai macam jenis pisang dapat tumbuh di Indonesia. Konsumsi buah pisang yang tinggi diikuti dengan melimpahnya kulit pisang. Kandungan nutrisi dari kulit pisang ini berpotensi untuk dikonversi menjadi produk lain yang mempunyai nilai ekonomis tinggi seperti asam laktat. Asam laktat banyak digunakan di industri pangan, farmasi maupun kosmetik. Pada penelitian ini bertujuan untuk mempelajari pengaruh metode fermentasi yaitu fermentasi substrat padat dan fermentasi substrat cair dalam memproduksi asam laktat dari kulit pisang dibantu Rhizopus oryzae. Penelitian ini terbagi dalam 3 tahap yaitu: (1) pembuatan media fermentasi, (2) fermentasi kulit pisang dan (3) pemurnian asam laktat dengan resin amberlite IRA-400. Untuk metode fermentasi substrat padat, kulit pisang kering digrinder hingga menjadi serbuk sedangkan untuk fermentasi substrat cair, kulit pisang yang masih segar diekstrak dengan pelarut air. Selanjutnya serbuk kulit pisang dan ekstrak kulit pisang siap untuk diinokulasi dengan Rhizopus oryzae dan diinkubasi pada suhu $30{ }^{\circ} \mathrm{C}$ selama 144 jam. Hasil penelitian menunjukkan bahwa yield asam laktat yang dihasilkan dari fermentasi substrat padat lebih tinggi $(0,79 \mathrm{~g}$ asam laktat / g pati) dibandingkan yield asam laktat dari fermentasi substrat cair $(0,15 \mathrm{~g}$ asam laktat / g pati).
\end{abstract}

Keywords: asam laktat, fermentasi substrat cair, fermentasi substrat padat, kulit pisang, Rhizopus oryzae

\section{Abstract}

SOLID SUBSTRATE AND LIQUID SUBSTRATE FERMENTATION FOR LACTIC ACID PRODUCTION FROM BANANA PEEL BY RHIZOPUS ORYZAE. Indonesia is one of the major banana producing countries in the world. There are many varieties of banana grown in Indonesia. While the fruit is valuable for consumption, banana peels mostly are discarded as waste. In fact, banana peels are high in nutrition, thus they are potential to be converted into other valuable products such as lactic acid. The objective of this research was to study the effect of fermentation methods, i.e. solid substrate fermentation and liquid substrate fermentation, in the production of lactic acid from banana peel waste by the fungus Rhizopus oryzae. There were three steps involved in this research: (1) preparation of fermentation medium, (2) banana peel fermentation, and (3) lactic acid purification and recovery by using Amberlite IRA-400 resin. In solid substrate fermentation, dried banana peels were firstly crushed, while in liquid substrate fermentation, fresh banana peels were extracted by water Following this, banana peel powder and extract banana peel were inoculated with Rhizopus oryzae and incubated at $30{ }^{\circ} \mathrm{C}$ for $144 \mathrm{~h}$. As results, the yield of lactic acid produced from solid substrate fermentation ( $0.79 \mathrm{~g}$ lactic acid/g starch) was higher than that from liquid substrate fermentation ( $0.15 \mathrm{~g}$ lactic acid $/ \mathrm{g}$ starch)

Kata kunci: lactic acid, liquid fermentation, solid state fermentation, banana peel, Rhizopus oryzae

*penulis korespondensi 


\section{PENDAHULUAN}

Salah satu limbah organik yang banyak dihasilkan di Indonesia adalah kulit pisang. Sebagai gambaran, produksi pisang di propinsi Jawa Timur saja pada tahun 2011 mencapai 1.188.724 ton. Produksi pisang ini didominasi oleh varietas pisang kepok, yang mencapai $40 \%$ dari total produksi (BPS, 2012). Dengan berat kulit pisang yang setara dengan 5/9 berat pisang keseluruhan, dapat dipastikan bahwa volume produksi limbah kulit pisang sangat besar. Selama ini kulit pisang digunakan sebagai makanan ternak di daerah pedesaan, tetapi di daerah perkotaan cenderung menjadi limbah yang kurang dimanfaatkan. Kandungan pati dan nutrisi yang ada di dalam kulit pisang (Tabel 1) memungkinkan untuk dimanfaatkan menjadi produk komersial yang lain, di antaranya asam laktat.

Tabel 1. Komposisi Kimia Kulit Pisang (Munadjim, 1984)

\begin{tabular}{lr}
\hline Unsur & Kadar, \%-berat \\
\hline Air & 68,90 \\
Lemak & 2,11 \\
Karbohidrat & 18,50 \\
Protein & 0,32 \\
Kalsium & 0,715 \\
Fosfor & 1,17 \\
Besi & 0,016 \\
\hline
\end{tabular}

Asam laktat banyak digunakan dalam industri seperti industri makanan, minuman, kosmetik, kimia, farmasi, dan plastik biodegradable (Naranong and Poocharoen, 2001). Pembuatan asam laktat dapat dilakukan dengan proses sintesis kimiawi maupun proses fermentasi. Kurang lebih sekitar 35\% dari total asam laktat yang diproduksi dibuat secara sintetik dan 65\% dengan cara fermentasi. Pembuatan asam laktat secara fermentasi lebih ramah lingkungan karena cenderung memanfaatkan bahan-bahan alam. Prinsip utama pembuatan asam laktat pada penelitian ini adalah mencakup proses sakarifikasi dan fermentasi yang dilakukan secara simultan (Huang dkk., 2005), baik menggunakan substrat cair maupun padat.

Produksi asam laktat secara fermentasi paling umum menggunakan bakteri Lactobacillus sp, karena perolehan yang cukup tinggi yaitu 80-90\% (Maas dkk., 2006), namun demikian, pemeliharaan bakteri membutuhkan media fermentasi dengan kandungan nutrisi ataupun suplemen yang lebih kompleks sehingga menambah biaya produksi asam laktat. Selain itu, rumitnya proses pemisahan $\mathrm{D}(-)$ dari $\mathrm{L}(+)$-asam laktat juga menambah biaya produksi apabila asam laktat tersebut akan dibuat menjadi Poly Lactic Acid (Maas dkk., 2006).

Pemanfaatan kapang Rhizopus oryzae untuk menghasilkan asam laktat merupakan alternatif mikroba yang perlu dipertimbangkan, karena kapang ini hanya menghasilkan L(+)-asam laktat saja. Keunggulan yang lain adalah dapat ditumbuhkan dengan minimal kandungan mineral dan garam ammonium sebagai sumber nitrogen baik media cair maupun padat (Soccol dkk., 1994; Maas dkk., 2006; Ellis, 2012).

Pembuatan asam laktat dengan bantuan kapang menggunakan metode fermentasi permukaan (surface fermentation) tanpa pengadukan masih sangat terbatas. Pembuatan asam laktat dengan bantuan kapang ini sudah banyak dilakukan tetapi dengan memanfaatkan kulit pisang sebagai substrat pada proses fermentasi permukaan (surface fermentation) tanpa pengadukan, sangat terbatas. Pada penelitian ini, limbah kulit pisang dimanfaatkan sebagai substrat atau media fermentasi. Rhizopus oryzae digunakan untuk menghasilkan asam laktat dengan metode fermentasi permukaan tanpa pengadukan dalam substrat cair maupun padat.

\section{METODE \\ Bahan}

Semua bahan kimia yang digunakan pada penelitian ini, yaitu $\mathrm{KH}_{2} \mathrm{PO}_{4}$, $\mathrm{MgSO}_{4} .7 \mathrm{H}_{2} \mathrm{O}, \quad \mathrm{ZnSO}_{4} .7 \mathrm{H}_{2} \mathrm{O}$ dan $\left(\mathrm{NH}_{4}\right)_{2} \mathrm{SO}_{4}$, merupakan bahan bermutu analitik dari Merck. Kulit pisang diperoleh dari pedagang gorengan di sekitar jalan Dharmawangsa di kota Surabaya. Kulit pisang yang digunakan berasal dari varietas pisang kepok.

Mikroorganisme yang membantu proses fermentasi adalah Rhizopus oryzae, yang berasal dari Departemen Biologi Universitas Airlangga Surabaya. Kapang ini ditumbuhkan pada medium Potato Dextrose Agar (PDA) dari Merck pada suhu $30{ }^{\circ} \mathrm{C}$ selama 144 jam.

\section{Preparasi Substrat Cair}

Ekstrak kulit pisang dibuat dari 1000 gram kulit pisang dicampur dengan $1 \mathrm{~L}$ air 
setelah itu diblender dan disaring. Selanjutnya setiap $100 \mathrm{~mL}$ ekstrak ditambahkan nutrisi $0,015 \mathrm{~g} \mathrm{KH}_{2} \mathrm{PO}_{4} ; 0,025 \mathrm{~g} \mathrm{MgSO}_{4} .7 \mathrm{H}_{2} \mathrm{O} ; 0,004 \mathrm{~g}$

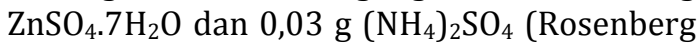
dkk., 1994).

\section{Preparasi Substrat Padat dan Fermentasi}

Kulit pisang dikeringkan dengan oven Memmert- SECM 400, hingga kadar air $\pm 8 \%$. Pengukuran kadar air dilakukan dengan alat moisture balance, OHAUS MB 200. Selanjutnya dikecilkan ukurannya dengan grinder dan diayak dengan shieve-shaker Heidolph Duomax 2030, hingga ukuran 14/16 mesh.

Pada fermentasi substrat cair, dilakukan pembuatan kultur starter terlebih dahulu, yang terdiri atas $20 \mathrm{~mL}$ ekstrak kulit pisang yang sudah dicampur dengan nutrisi dan $1 \mathrm{~mL}$ suspensi spora (konsentrasi $10^{7}$ spora / $\mathrm{mL}$ ). Selanjutnya, starter diinkubasi pada suhu $30{ }^{\circ} \mathrm{C}$ selama 96 jam. Setelah itu $100 \mathrm{~mL}$ ekstrak kulit pisang bernutrisi dicampur dengan starter dalam labu erlenmeyer $250 \mathrm{~mL}$ dan diinkubasi pada suhu $30{ }^{\circ} \mathrm{C}$ selama 144 jam.

Pada fermentasi substrat padat, tiap 5 gram kulit pisang ditambahkan $7 \mathrm{~mL}$ nutrisi dengan komposisi tiap $100 \mathrm{~mL}$ terdiri atas $0,135 \mathrm{~g}\left(\mathrm{NH}_{4}\right)_{2} \mathrm{SO}_{4} ; 0,03 \mathrm{~g} \mathrm{KH}_{2} \mathrm{PO}_{4} ; 0,004 \mathrm{~g}$ $\mathrm{ZnSO}_{4} .7 \mathrm{H}_{2} \mathrm{O}$ dan 0,025 g MgSO $_{4} .7 \mathrm{H}_{2} \mathrm{O}$ (Soccol dkk., 1994) dan $1 \mathrm{~mL}$ suspensi spora dengan konsentrasi $10^{7}$ spora/mL. Campuran ini selanjutnya diinkubasi pada suhu $30{ }^{\circ} \mathrm{C}$ selama 144 jam.

\section{Pemurnian dan Analisis Asam Laktat}

Pemurnian asam laktat hasil fermentasi dilakukan dengan menggunakan resin Amberlite IRA-400 (Cao dkk., 2002). Penentuan kadar gula reduksi menggunakan metode dinitrosalicylic acid (DNS) (Lee, 1992) dan diukur dengan spektrofotometer UV-Vis pada panjang gelombang $520 \mathrm{~nm}$. Konsentrasi asam laktat diukur dengan metode titrimetri.

\section{HASIL DAN PEMBAHASAN}

Kulit pisang kepok mengandung pati kurang lebih 89,94\% (berat kering) sehingga memungkinkan untuk digunakan sebagai sumber karbon bagi mikroorganisme yang menghasilkan enzim amilaseseperti Rhizopus oryzae (Huang dkk., 2005). Proses sakarifikasi dan fermentasi yang dilakukan secara simultan oleh Rhizopus oryzae ini dipelajari dalam 2 metode fermentasi yaitu dengan substrat cair dan padat. Perbedaan metode fermentasi ini digunakan untuk mempelajari potensi kulit pisang dalam menghasilkan asam laktat.

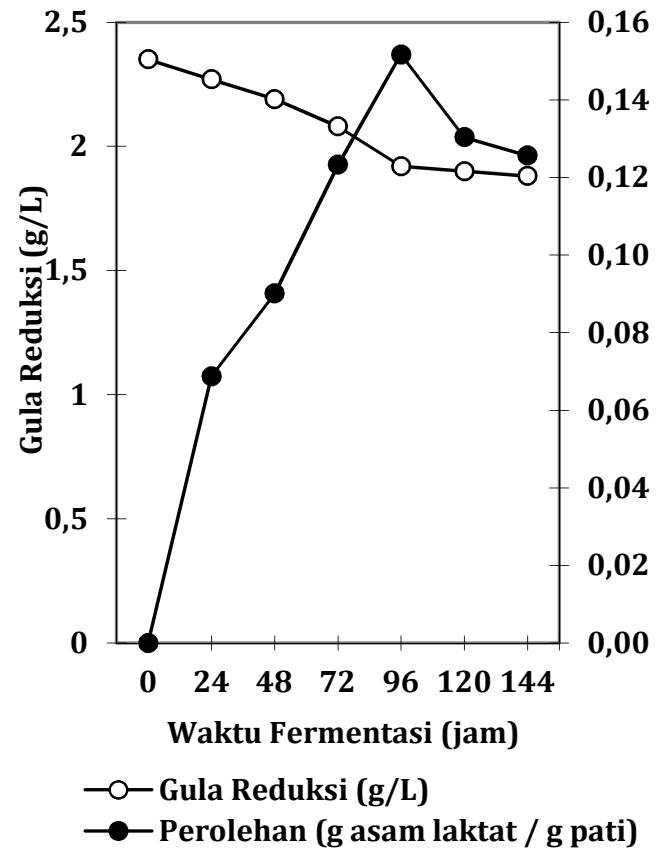

(a)

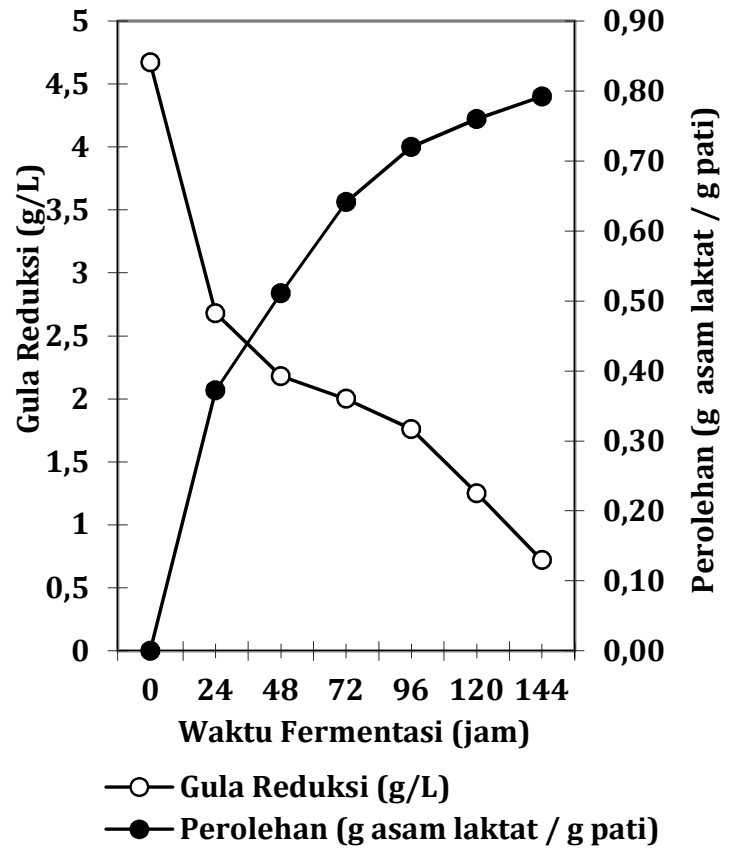

(b)

Gambar 1. Perubahan kadar asam laktat dan gula reduksi terhadap waktu pada (a) fermentasi substrat cair dan (b) fermentasi substrat padat, dengan substrat kulit pisang dan bantuan Rhizopus oryzae 
Pada fermentasi substrat cair (Gambar 1a), Rhizopus oryzae mengkonsumsi gula cukup tinggi $(0,43 \mathrm{~g} / \mathrm{L})$ dari waktu fermentasi 0-96 jam tetapi mengalami penurunan $(0,04$ g/L) pada waktu fermentasi 96-144 jam. Konsumsi gula yang tinggi tersebut diikuti dengan peningkatan perolehan asam laktat yang cukup tinggi pula yaitu $0,15 \mathrm{~g}$ asam laktat / g pati. Sebaliknya, konsumsi gula yang rendah diikuti penurunan perolehan asam laktat hingga 0,13 g asam laktat / g pati. Hal ini disebabkan karena saat konsumsi gula mulai menurun menunjukkan bahwa Rhizopus oryzae mulai berada di akhir fasa stasioner sehingga sebagian asam laktat yang sudah diproduksi digunakan untuk perawatan struktur sel (Bulut dkk., 2004).

Fermentasi substrat cair kulit pisang ini menggunakan teknik fermentasi surface culture, sehingga tidak dilakukan pengadukan. Rhizopus oryzae hanya tumbuh di permukaan cairan saja, sehingga luas tempat tumbuhnya terbatas pada luas penampang labu erlenmeyer.

Pada Gambar 1b, Rhizopus oryzae mengkonsumsi gula cukup tinggi $(2,91 \mathrm{~g} / \mathrm{L})$ dari waktu fermentasi 0-96 jam dan mengalami pengurangan konsumsi $(1,04 \mathrm{~g} / \mathrm{L})$ pada waktu fermentasi 96-144 jam. Konsumsi gula yang tinggi tersebut juga diikuti dengan peningkatan perolehan asam laktat yang tinggi pula, yaitu 0,72 g asam laktat / g pati dan mencapai nilai maksimum pada $0,79 \mathrm{~g}$ asam laktat / g pati. Hal ini disebabkan Rhizopus oryzae berada di fasa eksponensial sehingga kemampuan memanfaatkan pati sebagai sumber karbon dalam proses sakarifikasi cukup tinggi. Asam laktat merupakan hasil metabolisme primer (Shuler dan Kargi, 1992) yang mengikuti jalur Embden-Meyerhof-Parnas (EMP) (Salminen dan Wright, 1993). Berdasarkan jalur EMP tersebut, dapat diketahui bahwa $1 \mathrm{~mol}$ glukosa akan menghasilkan $2 \mathrm{~mol}$ asam laktat dengan bantuan enzim laktat dehidrogenase. Ini mengindikasikan bahwa banyaknya gula yang dikonsumsi oleh Rhizopus oryzae akan membuat produksi enzim laktat dehidrogenase juga tinggi dan pada akhirnya menyebabkan produksi asam laktat tinggi pula.

Berdasarkan Gambar 1a dan 1b, dapat dilihat bahwa pada fermentasi substrat cair, pertumbuhan Rhizopus oryzae lebih cepat untuk mencapai fase stasioner (96 jam) daripada fermentasi substrat padat (144 jam).
Keadaan ini dimungkinkan karena Rhizopus oryzae adalah kapang yang aerob, sehingga untuk pertumbuhannya sangat membutuhkan $\mathrm{O}_{2}$. Pada fermentasi substrat cair tanpa pengadukan, kemungkinan untuk mendapatkan suplai $\mathrm{O}_{2}$ yang cukup di dalam cairan sedikit, sehingga Rhizopus oryzae akan cenderung tumbuh hanya di permukaan media cair yang suplai $\mathrm{O}_{2}$-nya lebih tinggi yaitu berasal dari ruang kosong yang ada di atasnya. Hal ini pula yang menyebabkan perolehan asam laktat di fermentasi substrat padat lebih tinggi $(0,79 \mathrm{~g}$ asam laktat / g pati) daripada fermentasi substrat cair $00,15 \mathrm{~g}$ asam laktat / g pati).

Sebenarnya perolehan asam laktat di fermentasi substrat cair dapat ditingkatkan dengan cara melakukan pengadukan atau aerasi (Naranong dan Poocharoen, 2001) tetapi karena pada kajian ini fermentasi substrat cair dan substrat padat menggunakan metode fermentasi permukaan, maka tidak dilakukan pengadukan.

\section{KESIMPULAN}

Metode fermentasi permukaan (surface fermentation) lebih baik diaplikasikan pada substrat padat daripada substrat cair apabila digunakan kapang yang aerob yaitu membutuhkan oksigen dalam pertumbuhannya. Pada fermentasi kulit pisang untuk produksi asam laktat, perolehan asam laktat dari fermentasi substrat padat lebih tinggi $(0,79$ g asam laktat / g pati) dibandingkan dari fermentasi substrat cair $(0,15$ g asam laktat / g pati).

\section{DAFTAR PUSTAKA}

Badan Pusat Statistik, Produksi Buah-Buahan Menurut Propinsi 2011, 2012, http://www.bps.go.id/tab_sub/view.php?kat =3\&tabel=1\&daftar=1\&id_subyek=55\&notab= 21 (akses 1 Mei 2012)

Bulut, S.; Elibol, M.; Ozer, D., Effect of different carbon sources on L(+)-lactic acid production by Rhizopus oryzae, Biochemical Engineering Journal, 2004, 21(1), 33-37.

Cao, X.; Yun, H. S .; Koo, Y. M., Recovery of L(+) lactic acid by anion exchange resin amberlite IRA-400, Biochemical Engineering Journal, 2002, 11(2-3), 189-196.

Ellis, D., Rhizopus oryzae, 2012, http://www. mycology.adelaide.edu.au/Fungal_Description 
s/Zygomycetes/Rhizopus/R_oryzae.html (akses 1 Mei 2012).

Huang, L. P.; Jin, B.; Lant, P.; Zhou, J., Simultaneous saccharification and fermentation of potato starch wastewater to lactic acid by Rhizopus oryzae and Rhizopus arrhizus, Journal of Biochemical Engineering, 2005, 23(3), 265-276.

Lee, J. M., Biochemical Engineering; Prentice Hall: New Jersey, 1992; hlm. 94-95.

Maas, R. H. W.; Bakker, R. R.; Eggink, G.; Weusthuis, R. A., Lactic acid production from xylose by the fungus Rhizopus oryzae, Applied Microbiol Biotechnol, 2006, 72(5), 861-868.

Munadjim, Teknologi Pengolahan Pisang; PT Gramedia: Jakarta, 1984; hlm. 16-63.

Naranong, N.; Poocharoen, D., Production of Llactic acid from raw cassava starch by
Rhizopus oryzae NRRL 395, Kasetsart Journal: Natural Science, 2001, 35, 164-170.

Rosenberg, M.; Kristofikova, L.; Sturdik, E., Influence of carbohydrates and polyols on Llactic acid production and fatty acid formation by Rhizopus arrhizus, World Journal Microbiology and Biotechnology, 1994, 10(3), 271-274.

Salminen, S.; Wright, A. V., Lactic Acid Bacteria; Marcel Dekker: New York, 1993; hlm. 4-88, 20-23, 295-296.

Shuler, M. L.; Kargi, F., Bioprocess Engineering: Basic Concepts; Prentice Hall PTR: London, 1992; hlm.74-76, 97, 159, 160.

Soccol, C. R.; Marin, B.; Raimbault, M.; Lebeault, J. M., Potential of solid state fermentation for production of $\mathrm{L}(+)$-lactic acid by Rhizopus oryzae, Applied Microbiology and Biotechnology, 1994, 41(3), 286-290. 